\title{
How does calorie restriction work?
}

\author{
Jana Koubova and Leonard Guarente ${ }^{1}$ \\ Department of Biology, MIT, Cambridge, Massachusetts 02139, USA
}

For almost 70 years, calorie restriction has been known to extend life span. Despite the extensive physiological characterization of this dietary regimen, the molecular basis for the slowing in aging remains unsolved. Recent findings have pinpointed a few molecular pathways that appear to regulate the aging process. In this review, we propose a molecular model for how calorie restriction works that incorporates these recent findings.

Calorie restriction $(\mathrm{CR})$ refers to a dietary regimen low in calories without undernutrition. It was first noted in the 1930s that food restriction significantly extends the life span of rodents (McCay et al. 1935). This longevity results from the limitation of total calories derived from carbohydrates, fats, or proteins to a level $25 \%-60 \%$ below that of control animals fed ad libitum (Richardson 1985; Weindruch et al. 1986). The extension in life span can approach $50 \%$ in rodents (Sohal and Weindruch 1996). CR extends life span in a remarkable range of organisms, including yeast, rotifers, spiders, worms, fish, mice, and rats (Weindruch and Walford 1988). Emerging data show that its effect may also apply to nonhuman primates (Lane et al. 2001).

$\mathrm{CR}$ delays a wide spectrum of diseases in different experimental animals; for example, kidney disease, a variety of neoplasias, autoimmune disease, and diabetes (Fernandes et al. 1976; Sarkar et al. 1982; Fernandes and Good 1984; Kubo et al. 1984; Engelman et al. 1990; Shields et al. 1991; Johnson et al. 1997). CR reduces ageassociated neuronal loss in most mouse models of neurodegenerative disorders such as Parkinson's disease (Duan and Mattson 1999) or Alzheimer's disease (Zhu et al. 1999). However, beneficial effects in a mouse model for amyotrophic lateral sclerosis were not observed (Pedersen and Mattson 1999). The CR regimen also prevents age-associated declines in psychomotor and spatial memory tasks (Ingram et al. 1987) and loss of dendritic spines necessary for learning (Moroi-Fetters et al. 1989) and improves the brain's plasticity and ability for selfrepair (Mattson 2000).

Why does CR exert these effects? Because CR delays reproduction and promotes survival in times of scarcity, it may have been evolutionarily adaptive during boom/ bust cycles (Harrison 1989; Holliday 1989). Despite the

${ }^{1}$ Corresponding author.

E-MAIL leng@mit.edu; FAX (617) 253-8699.

Article published online ahead of print. Article and publication date are at http://www.genesdev.org/cgi/doi/10.1101/gad.1052903. plausibility of this reasoning, several challenges to the significance of CR studies in the laboratory have been made. Perhaps the restricted animals live longer simply because controls are overfed to the point of ill health. However, regimens in which animals are fed controlled amounts of food rather than ad libitum still show beneficial effects of low calories (Weindruch and Walford 1988). Another objection is that inbred strains of rodents are not representative of animals in the wild. For example, lab strains are selected for rapid reproduction and large litters (Miller et al. 1999). It has been argued that these animals may accordingly have shorter life spans than wild strains. By this reasoning, CR may simply correct a defect that has been created by domestication. However, the generality of CR in many different organisms, as mentioned above, supports the argument against this criticism.

Even though benefits of CR have been known for many years, the mechanism(s) of its action remains unclear. Its complexity lies in multiple effects including metabolic, neuroendocrine, and apoptotic changes, which vary in intensity and exhibit striking differences among specific organ systems. Several major models to explain CR exist, but none satisfactorily integrates all of CR's effects. In this review, we address the question of how CR might function to extend life span. We begin with a summary of several aging theories and classical views about the action of CR. Then we discuss how CR extends the life span in Saccharomyces cerevisiae. We extrapolate these findings from yeast to mammals and consider metabolic, neuroendocrine, and apoptotic shifts that may trigger longevity in the higher organisms. We conclude with a model of CR that integrates its effects on mammals.

\section{Mechanisms of aging and classical views on how CR works}

Evolutionary biologists have argued that aging is a consequence of the inability of natural selection to cull out undesirable characteristics in a postreproductive phase of life. In the wild, for example, rodents may rarely experience a postreproductive period because of early death, for example, by predation. This implies that aging is multifactorial with many mechanisms contributing to the decline. Nonetheless, ideas that one or a few specific mechanisms may lie at the heart of aging have gained currency. A leading theory is that aging is caused by 
cumulative oxidative damage generated by reactive oxygen species (ROS) produced during respiration (Harman 1988). Oxidative damage to DNA, RNA, protein, and lipids has indeed been demonstrated to occur with aging (Fraga et al. 1990; Stadtman 1992; Head et al. 2002; Liu et al. 2002). Some investigators argue that this damage may limit life span. For example, overexpression of the enzyme superoxide dismutase (SOD), which reduces ROS, extends life span in Drosophila (Parkes et al. 1998) and in stationary phase yeast cells (Longo et al. 1999).

How might CR slow down the generation of damage in cells? It has been documented that oxidative damage is reduced in CR animals (Lee and Yu 1990). If CR were to slow metabolism, the production of ROS would decrease as a simple consequence. However, studies measuring metabolic rate in CR animals give conflicting results. The weight of evidence in rodents indicates that metabolism, as measured by oxygen consumption normalized to the reduced body mass of the animal, does not slow down (McCarter et al. 1985). Because the balance of existing data does not support a long-term overall reduction in metabolic rate, more subtle explanations must be adduced. One possibility is that a more efficient transport of electrons through the respiratory chain might reduce the production of ROS and slow aging (Weindruch et al. 1986; Duffy et al. 1989, 1990). Another is that an increased ability to detoxify ROS slows oxidative damage in CR. The data relating CR to detoxification of ROS is again conflicting. On the one hand, organisms tend to be more resistant to an acute challenge by an exogenous oxidative stressor. For example, life-long CR seems to increase expression of SOD in rat liver (Semsei et al. 1989). On the other hand, in genetically altered strains of mice, there is no consistent correlation in the expression levels of SOD and life span (Hauck and Bartke 2000).

Another theory suggests that lack of protein turnover may cause aging. Multiple studies of aging organisms have shown accumulation of aberrant (e.g., oxidatively damaged) proteins and a reduction in protein turnover (Lavie et al. 1982; Gracy et al. 1985). CR may slow down accumulation of these potentially harmful abnormal proteins by speeding up protein turnover (Taylor et al. 1989; Sohal and Weindruch 1996). How can CR accomplish this? As the body runs out of fat during CR, it may trigger the degradation of proteins, thereby increasing their turnover. Indeed, the age-associated accumulation of oxidized proteins declines with CR (Aksenova et al. 1998; Dhahbi et al. 1999), and the activity of the liver $20 \mathrm{~S}$ proteosome may increase during CR (Scrofano et al. 1998). Microarray study of mouse skeletal muscle also showed an increase in protein synthesis and degradation during CR (Lee et al. 1999). However, the elevated turnover during CR is not uniform; although some damaged proteins were degraded, others continued to accumulate (Scrofano et al. 1998). All told, the data suggest an increase in protein turnover during CR, but whether this change has an impact on the rate of aging is uncertain.

The covalent modification of proteins by derivatives of glucose has also been shown to increase with age (Masoro et al. 1989; Smith et al. 1994; Cefalu et al. 1995; Sell et al. 1996). These modified adducts in macromolecules, termed advanced glycation end products (AGE), have been linked to age-related pathologies (Lee and Cerami 1992). A reduction of AGE during CR has been demonstrated (Masoro et al. 1989; Cefalu et al. 1995). The blood profile of CR animals predicts this reduction, because both glucose and insulin levels are reduced in CR animals (Masoro et al. 1983, 1992). However, a lower percentage of AGE during CR does not clearly explain the multiple other effects that are known to occur. It is unlikely that a decrease in AGE is responsible for the long life span in CR, because AGE is one of many degenerative changes in aging.

The same logic argues against any model proposing a single effect of CR on a mechanical aspect of the aging process, including the antioxidation model above (Fig. 1A). As we discuss below, studies on CR in yeast suggest that the increase in life span is a regulated response to food deprivation. Indeed, a regulated response to CR may account for the plethora of effects required to slow the wholesale decline in aging (Fig. 1B).

\section{Regulation of yeast replicative life span by CR}

In budding yeast, mother cells divide asymmetrically, giving rise to a newly made daughter cell and an aging mother cell. The mother cell adopts phenotypes of aging, including an enlarged size and sterility, and senesces after $\sim 20$ divisions. This aging has been linked to the repeated rDNA genes, which encode the large and small subunits of ribosomal RNA (Sinclair and Guarente 1997). Aging mother cells accumulate extrachromosomal rDNA circles, and mutations that slow the generation of these circles extend the life span. However, this rDNA instability has not been observed in other organisms, and is evidently an idiosyncratic feature of yeast aging.

The SIR2 gene regulates the life span in yeast mother cells; mutations that inactivate SIR2 shorten the life span, and overexpression of SIR2 extends it (Kaeberlein et al. 1999). SIR2 functions to silence chromatin by deacetylating the histones in targeted regions of the yeast genome, including the rDNA. The silenced chro-

A

Mechanical:

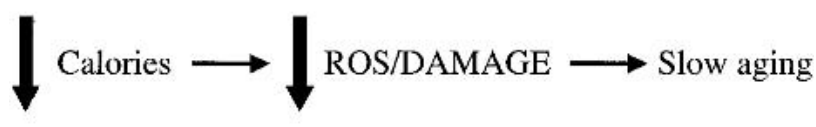

B

Regulated:

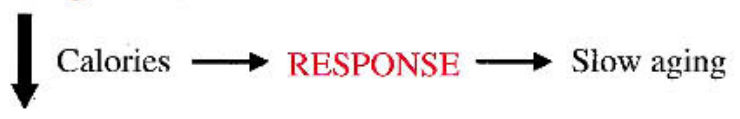

Figure 1. Two general mechanisms for how calorie restriction extends life span. 
matin is structurally less accessible to RNA polymerase and to recombinational enzymes, thereby reducing gene expression and stabilizing repeated DNA. The Sir2p deacetylase is unusual because it requires NAD as a cosubstrate (Imai et al. 2000; Landry et al. 2000; Smith et al. 2000). NADH, NADP, and NADPH neither activate nor inhibit the enzyme (Imai et al. 2000).

$\mathrm{CR}$ can be imposed in yeast by reducing the glucose concentration in the media from the usual $2 \%$ to $0.5 \%$ (Fig. 2; Lin et al. 2000). Because cells continue to feed on yeast extract plus peptone, which are rich in amino acids, nucleotides, and vitamins, the growth rate remains rapid as glucose levels are lowered. Thus, the reduction in glucose from $2 \%$ to $0.5 \%$, although modest, likely imposes a state of partial energy (ATP) limitation. Other dietary restriction protocols, which also limit amino acids and other nutrients (Jiang et al. 2000, 2002), drastically slow the growth rate and may make it more difficult to impose energy limitation.

Under our conditions of CR, mother cells divide $\sim 30 \%$ more times. This additional life span does not occur in a sir2 mutant or in strains in which NAD synthesis is reduced (Lin et al. 2000). Therefore, the activity of Sir2p is required to deliver the long life span by $\mathrm{CR}$, and indeed, the silencing activity of Sir2p was shown to increase in CR cells.

How does CR activate Sir2p in yeast? When the glucose levels in the media are lowered, yeast cells respond by shunting more of the carbon to the TCA cycle to generate ATP by respiration (Lin et al. 2002). This comes at the expense of fermentation, which is the preferred pathway of carbon use when glucose levels are high. This metabolic shift makes sense because cells harvest much more ATP by metabolizing the glucose to $\mathrm{CO}_{2}$ in the TCA cycle than by fermenting it to ethanol.

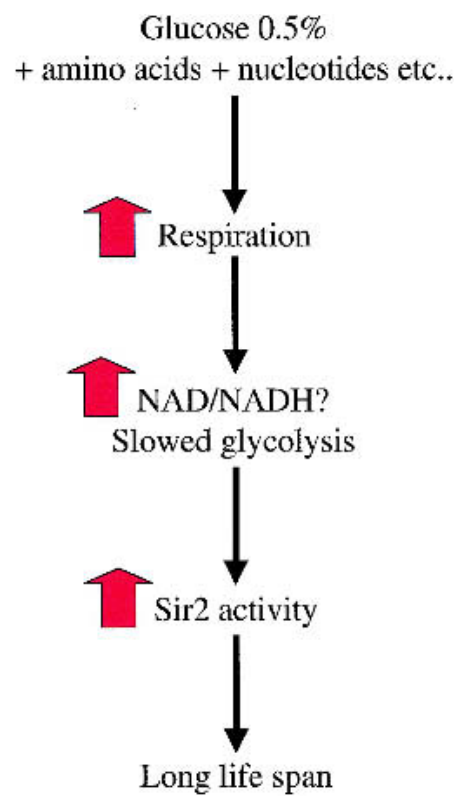

Figure 2. Calorie restriction triggers a regulatory response in yeast.
The shift toward respiration is necessary and sufficient to extend the life span in yeast. It is still not certain how this shift activates Sir2p to provide greater longevity. One possibility is that the activation of respiration converts more NADH to NAD and the resulting increase in the NAD/NADH ratio activates Sir2p. It has also been suggested that nicotinamide, which is generated during the deacetylation reaction and can inhibit Sir2p in vitro, is a negative regulator of Sir2p in vivo (Bitterman et al. 2002). There is still no direct evidence for either of these models. Another possibility is that the increase in respiration during CR slows glycolysis, and this metabolic change activates Sir2p. Any mechanism for this latter effect is at present unknown.

The important lesson from the yeast studies is that the extension in life span by CR is not a mechanical consequence of a reduction in ROS or AGE. Rather, the extension is a regulated response requiring SIR2 (Fig. 1). This regulation must involve a qualitative shift in metabolism that can be sensed by Sir2p. The deacetylase activity of the enzyme must then slow any degenerative processes that limit the life span.

\section{Metabolic changes during $\mathrm{CR}$ in mammals}

Studies suggest that there are two phases of CR in mammals, an adaptive period immediately after the regimen is imposed, and a steady state period, which can last the lifetime of the animal. During the adaptive phase, metabolism, as measured by oxygen consumption, declines (McCarter and McGee 1989). Glucose metabolism regulates secretion of insulin from the pancreatic $\beta$-cells. Interestingly, the $\beta$-cells in the pancreas that make insulin have been reported to sense glucose not by the production of ATP but by the conversion of NAD to NADH (Dukes et al. 1994; Eto et al. 1999; Antinozzi et al. 2002).

In the immediate response to low levels of glucose, the restricted animal quickly degrades glycogen stores upon the secretion of glucagon from the pancreas. When stored carbohydrates have been depleted, the animal starts to break down fats to compensate for the lack of glucose in the blood (Bertrand et al. 1980). As a result, loss of fat mass is one of the most striking phenotypic changes observed in calorically restricted animals (Barzilai and Gabriely 2001). The liver assumes a dominant role during CR by up-regulating the expression of enzymes involved in gluconeogenesis and down-regulating those in glycolysis (Dhahbi et al. 1999, 2001). Moreover, the liver makes ketones, such as acetoacetate, that result from the degradation of fat and proteins in the animal (Fig. 3).

After this adaptive period, the organism reaches a steady state in which ketones help meet energy needs of the brain. Thus, blood glucose falls precipitously during the adaptive period, and rises to a higher, but still belownormal level during the steady state (Greene et al. 2001). $\beta$-Cells sense the low glucose levels, and produce less insulin. The blood insulin level is lower than in control animals, and insulin sensitivity, that is, the efficacy of insulin in triggering glucose uptake by cells, is higher 
Figure 3. Metabolic pathways affected by calorie restriction in mammals. Red implies up-regulation, black implies down-regulation or no change.

(Reaven et al. 1983; Masoro et al. 1992; Cartee et al. 1994; Dhahbi et al. 2001).

Another metabolic alteration during CR in rodents, as well as in nonhuman primates, is a reduction in body temperature (Weindruch and Walford 1988; Duffy et al. 1990; Lane et al. 1996). This change may be due to an increase in the coupling of oxidative phosphorylation to ATP synthesis, perhaps by a reduction in levels of uncoupling proteins. These proteins span the inner membrane of the mitochondria and may allow proton leakage and thus hijack a fraction of the energy of electron transport to generate heat rather than ATP (Weindruch et al. 2001).

\section{CR and the neuroendocrine system}

The neuroendocrine system has long been thought to play a role in senescence (Landfield 1978; Finch et al. 1984; Sapolsky et al. 1986; Weindruch and Walford 1988). An attractive feature of this system is that it can coordinate effects on every tissue in the body (Nelson et al. 1995). Studies from Caenorhabditis elegans also provide strong evidence for the importance of hormones in aging, in particular for hormones involved in glucose metabolism. daf-2 is a worm ortholog to receptors for insulin and for its related peptide hormone, IGF-1 (Kimura et al. 1997). Mutant worms with reduced functional daf-2 (or several other components of the insulin/IGF-1 pathway, such as age-1 or pdk-1) live longer (Kenyon et al. 1993). Furthermore, the insulin/IGF-1 signaling pathway in worms is also responsible for triggering developmental arrest at the L2 larval stage in response to stress, such as the lack of food (Finch and Ruvkun 2001). These arrested L2 larvae, termed dauers, survive for long periods and can resume development to adulthood when conditions improve.

Many changes observed in the CR rodents trace directly or indirectly to changes in the neuroendocrine system. CR animals routinely have lower levels of the pituitary growth hormone (GH), thyroid stimulating hormone, IGF-1, and gonadotropins (Mobbs et al. 2001).
Conversely, glucocorticoids, catecholamines, and glucagons increase (Klebanov et al. 1995; Mobbs et al. 2001). Mutations that affect expression of several hormones have also been shown to prolong life span. For example, Ames dwarf mice carry a loss-of-function mutation in the gene Pit ${ }^{\mathrm{dw}}$ (Brown-Borg et al. 1996) that leads to abnormally low expression of GH (Sornson et al. 1996). Because GH normally turns on expression of IGF-1 in the liver, these mutant mice also have low levels of IGF-1 (Bartke et al. 1998; Coschigano et al. 2000). Ames dwarf mice live longer than wild type (Brown-Borg et al. 1996), whereas transgenic mice secreting large amounts of $\mathrm{GH}$ have a shortened life span (Laron 2002).

The synthesis and release of GH from the pituitary is controlled by the hypothalamus. This compartment of the brain releases hormones, such as growth-hormonereleasing hormone, that stimulate the release of $\mathrm{GH}$ from the pituitary. Interestingly, particular neurons in the hypothalamus may also stimulate the release of $\mathrm{GH}$ (Mobbs et al. 2001). The brain's ability to sense glucose is accomplished via a subset of hypothalamic neurons, which can sense the sugar and fire in response to threshold changes in its concentration. Amazingly, like the $\beta$-cells in the pancreas, these hypothalamic neurons sense glucose by the conversion of NAD to NADH (Yang et al. 1999). We speculate below that mammalian Sir2 proteins in the hypothalamus (and pancreas), because they are NAD-dependent deacetylases, sense CR and mediate the down-regulation of GH (and insulin).

Molecular analysis has the potential to strengthen the clues provided by the physiological and cellular studies above. Transcription profiling provides useful information in the brain. Expression of 6347 murine genes in 5and 30-month-old mice, as well as CR versus control animals, was analyzed by microarrays (Lee et al. 2000). Several interesting patterns of gene expression were observed. First, genes reflecting oxidative stress and inflammation were induced in 30-month-old control mice. This induction did not occur in age-matched CR animals. Second, genes involved in protein synthesis were 
the largest class reduced in expression during CR. A reduction in protein synthesis in the brain is not surprising, because the CR brain derives much of its energy from ketones, which are less energy-rich than glucose. Third, the expression of genes for growth and neurotrophic factors increased during CR. This includes genes encoding neuroplasticity factors such as neuroserpin. This finding may help explain the improved psychomotor performance observed in CR animals (Ingram et al. 1987).

\section{Links between CR, aging, and apoptosis}

Several recent studies suggest that apoptosis may limit mammalian life span. Mice with a targeted disruption in the p66shc gene exhibit a longer life span than wild-type animals (Migliaccio et al. 1999). Importantly, cells derived from the p66shc mice are resistant to DNA-damage-induced apoptosis in culture. Further, p66shc is one of the down-stream targets of the key regulator of damage-induced apoptosis, the tumor suppressor p53 (Trinei et al. 2002). In the cell culture studies, p66shc cells were resistant to oxidative stress or ionizing radiation, which both kill cells by the p53-dependent cell death pathway. This finding suggests that apoptosis may be a two-edged sword, providing critical tumor surveillance during the reproductive years, but contributing to organ dysfunction and aging in a postreproductive period.

A second finding may also implicate apoptosis in mammalian aging. The yeast SIR2 gene appears to promote survival in a wide range of organisms. In yeast this gene promotes long life span in mother cells, and is also crucial to the generation of the long-surviving, specialized cell type termed spores. In C. elegans, an organism that diverged from the yeast lineage a billion years ago, the SIR2 ortholog sir-2.1 also promotes long life in adult animals and regulates the formation of dauers during development (Tissenbaum and Guarente 2001). Recently, it has been shown that a cytoplasmic Sir2p homolog can promote survival in the protozoan parasite Leishmania by preventing apoptosis (Vergnes et al. 2002). The mammalian ortholog of SIR2, SIRT1, represses the activity of p53 and therefore down-regulates apoptosis (Luo et al. 2001; Vaziri et al. 2001). If the survival function of SIR2 genes observed in yeast, worms, and protozoans extends to mammals, apoptosis may thus be important in limiting mammalian life span.

Furthermore, a hyperactive allele of p53 has been described that confers enhanced tumor surveillance on transgenic mice (Tyner et al. 2002). Interestingly, these mice develop early organ degeneration and signs of premature aging. These phenotypes further support the idea that apoptosis may limit mammalian life span, because its enhancement apparently speeds up the aging process.

The above studies raise the possibility that any process extending mammalian life span would have to slow down apoptosis. However, in some organs with rapidly dividing cells, apoptosis actually increases during CR, for example, in the liver (James et al. 1998) and the gut (Holt et al. 1998). This increase, along with the known shrinkage of cells during CR (Birchenall-Sparks et al.
1985), may both contribute to the down-sizing of these organs in the restricted animal. The increased rate of apoptosis may minimize the risk of cancer during CR (James et al. 1998). The increase in apoptosis in these organs appears at odds with any central role for SIR2. However, it is possible that neuroendocrine changes are dominant in up-regulating apoptosis in this subset of organs.

The brain is the one organ that does not shrink during CR (Keenan et al. 1995; Weindruch and Sohal 1997). Is it possible that the link between apoptosis and life span discussed above is due to effects on neurons? Could p66shc KO mice live longer because neuronal death is slowed? It would be of interest to determine whether CR slows cell death of neurons. This may be difficult to visualize in animals, because apoptosis is transient and the number of apoptotic cells at any given time will be low. However, it may be possible to test whether interventions that slow aging, such as $\mathrm{CR}$, result in less apoptosis when neuronal cells are harvested and cultured.

\section{Model for CR effects on mammalian aging}

We have described metabolic, hormonal, and other changes, which coalesce to slow aging and extend the life span of animals during CR. Several classical models for CR propose a mechanical basis for the slowing of aging and extension of life span. For example, the accumulation of damage by oxidation or glycation may be expected to slow down as a consequence of reducing calories in the diet. But experiments in yeast show that the added life span during CR is not a mechanical output of low calories, but a process that is highly regulated. In this organism, CR triggers a metabolic shift toward respiration that activates the regulator SIR2. Could the extension in mammalian life span by CR also be a regulated process?

We can model the chain of events that follows the imposition of CR in mammals (Fig. 4). We speculate that the altered physiology resulting from lower levels of calories induces primary changes in the neuroendocrine system. As mentioned above, glucose-sensing neurons in the hypothalamus, as well as $\beta$-cells in the pancreas, somehow recognize a slowing in the rate of conversion of NAD to NADH during CR. This metabolic change likely results in a reduction in the secretion of growth hormone from the pituitary and insulin from the pancreas. Low GH would in turn reduce levels of IGF-1 made by the liver. In addition to affecting IGF-1, the lowering of other pituitary hormones, the gonadotropins, slows reproductive capabilities of the animal.

We speculate that mammalian Sir2 proteins may play roles at two critical positions in the pathway of CR effects on aging. The first would occur during the sensing of $\mathrm{CR}$, leading to changes in levels of hormones in the blood stream. Because Sir2 proteins are NAD-dependent deacetylases, they are well suited to this regulatory function and may play key roles in the pituitary and pancreas in sensing the conversion of NAD to NADH and resetting the levels of insulin and IGF-1 that are released. Such a mechanism would bespeak a conserved role of 


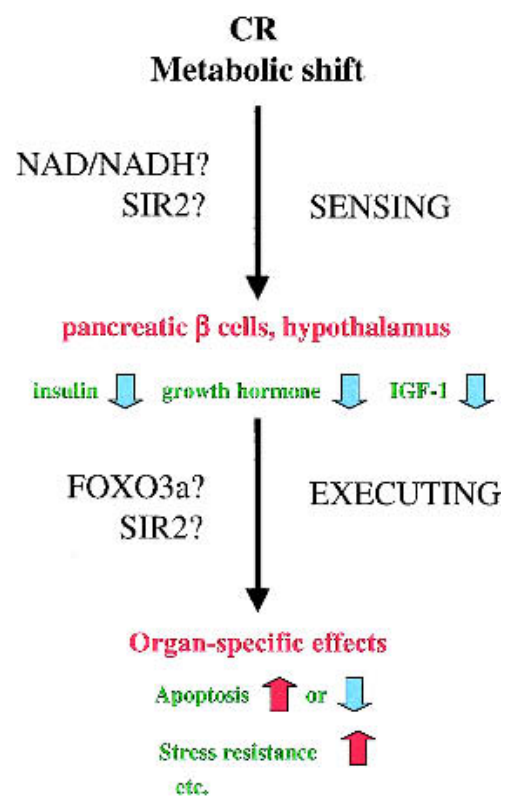

Figure 4. Model of how calorie restriction may extend life span in mammals. Effects occur at two levels: (1) sensing CR to adjust hormonal levels and (2) executing a slowing of aging on all organs. Roles for Sir2 genes are proposed at both levels, as discussed in the text.

Sir2 proteins as sensors of CR from yeast to mammals. The resulting endocrinological changes would allow the animal to mount a coordinated regulatory response to CR in different tissues.

Any hormonal changes must execute their effects by slowing aging in the animal. This execution phase is likely mediated, at least in part, by the insulin and IGF-1 signaling pathways in receptor-bearing cells. The precise effects of the hormone-receptor interaction may vary from organ to organ, because different cells bear different constellations of regulators. In general, however, longevity-promoting effects are expected to result from decreasing the insulin and IGF-1 pathways. In both C. elegans and mammals, these pathways impinge on transcription factors of the forkhead family. The worm factor is Daf-16 and the mammalian homologs are FOXO1-FOXO3. Decreased signaling by insulin/IGF-1 activates forkhead transcription factors, which in turn increase resistance to stress in mammalian cells (Nemoto and Finkel 2002; Tran et al. 2002) and worms (Guarente and Kenyon 2000). An increase in stress resistance is a hallmark of CR in a wide variety of organisms.

Changes that are not mediated by hormones may also be important. For example, metabolic changes on their own may directly slow aging in organs. In this regard, mammalian Sir2 proteins may play a pivotal role in some organs by recognizing the altered metabolism. If the metabolic shift during CR increases the activity of SIR2 in tissues with nondividing cells, it may directly slow apoptosis and age-dependent degeneration of organs such as the brain and perhaps the heart. Finally, metabolism-mediated changes in cells may synergize with changes in the levels of circulating insulin/IGF-1 hormones. In this regard, it is interesting that the worm sir-2.1 extends life span by down-regulating the insulin/ IGF-1 responsive signaling pathway. It is tempting to speculate that mammalian Sir2 proteins play a second role during this execution phase of CR by modulating the insulin and IGF-1 signaling pathways in hormoneresponsive cells.

Extension of life span by CR in mammals is a multidimensional phenomenon, which has ramifications ranging from endocrinology to metabolism to cell biology. In this review, we have discussed a regulatory model for how CR could extend life span in mammals. The studies in yeast imply that the extension of life span by $\mathrm{CR}$ is a regulated process. It is important therefore to consider regulatory mechanisms in any discussion of how CR slows aging in mammals. We have proposed one such model of how a coordinated global response to metabolic changes could work.

\section{Acknowledgments}

We apologize to those we did not cite because of space constraints. We thank Marcia Haigis, Gregory Hersch, and Paolo Tomasi for reading the manuscript. Work in the lab of L.G. was supported by the grants from the NIH, the Ellison Medical Foundation, and the Howard and Linda Stern Fund. J.K. was supported by the Presidential Fellowship of MIT.

\section{References}

Aksenova, M.V., Aksenov, M.Y., Carney, J.M., and Butterfield, D.A. 1998. Protein oxidation and enzyme activity decline in old brown Norway rats are reduced by dietary restriction. Mech. Ageing Dev. 100: 157-168.

Antinozzi, P.A., Ishihara, H., Newgard, C.B., and Wollheim, C.B. 2002. Mitochondrial metabolism sets the maximal limit of fuel-stimulated insulin secretion in a model pancreatic $\beta$ cell: A survey of four fuel secretagogues. J. Biol. Chem. 277: 11746-11755.

Bartke, A., Brown-Borg, H.M., Bode, A.M., Carlson, J., Hunter, W.S., and Bronson, R.T. 1998. Does growth hormone prevent or accelerate aging? Exp. Gerontol. 33: 675-687.

Barzilai, N. and Gabriely, I. 2001. The role of fat depletion in the biological benefits of caloric restriction. J. Nutr. 131: 903S906S.

Bertrand, H.A., Lynd, F.T., Masoro, E.J., and Yu, B.P. 1980. Changes in adipose mass and cellularity through the adult life of rats fed ad libitum or a life-prolonging restricted diet. J. Gerontol. 35: 827-835.

Birchenall-Sparks, M.C., Roberts, M.S., Staecker, J., Hardwick, J.P., and Richardson, A. 1985. Effect of dietary restriction on liver protein synthesis in rats. J. Nutr. 115: 944-950.

Bitterman, K.J., Anderson, R.M., Cohen, H.Y., Latorre-Esteves, M., and Sinclair, D. 2002. Inhibition of silencing and accelerated aging by nicotinamide, a putative negative regulator of yeast Sir2 and human SIRT1. J. Biol. Chem. 277: 4509945107.

Brown-Borg, H.M., Borg, K.E., Meliska, C.J., and Bartke, A. 1996. Dwarf mice and the ageing process. Nature 384: 33.

Cartee, G.D., Kietzke, E.W., and Briggs-Tung, C. 1994. Adaptation of muscle glucose transport with caloric restriction in adult, middle-aged, and old rats. Am. J. Physiol. 266: R1443R1447. 
Cefalu, W.T., Bell-Farrow, A.D., Wang, Z.Q., Sonntag, W.E., Fu, M.X., Baynes, J.W., and Thorpe, S.R. 1995. Caloric restriction decreases age-dependent accumulation of the glycoxidation products, $\mathrm{N} \epsilon$-(carboxymethyl)lysine and pentosidine, in rat skin collagen. J. Gerontol. A Biol. Sci. Med. Sci. 50: B337-B341.

Coschigano, K.T., Clemmons, D., Bellush, L.L., and Kopchick, J.J. 2000. Assessment of growth parameters and life span of GHR/BP gene-disrupted mice. Endocrinology 141: 26082613.

Dhahbi, J.M., Mote, P.L., Wingo, J., Tillman, J.B., Walford, R.L., and Spindler, S.R. 1999. Calories and aging alter gene expression for gluconeogenic, glycolytic, and nitrogen-metabolizing enzymes. Am. J. Physiol. 277: E352-E360.

Dhahbi, J.M., Mote, P.L., Wingo, J., Rowley, B.C., Cao, S.X., Walford, R.L., and Spindler, S.R. 2001. Caloric restriction alters the feeding response of key metabolic enzyme genes. Mech. Ageing Dev. 122: 1033-1048.

Duan, W. and Mattson, M.P. 1999. Dietary restriction and 2-deoxyglucose administration improve behavioral outcome and reduce degeneration of dopaminergic neurons in models of Parkinson's disease. J. Neurosci. Res. 57: 195-206.

Duffy, P.H., Feuers, R.J., Leakey, J.A., Nakamura, K., Turturro, A., and Hart, R.W. 1989. Effect of chronic caloric restriction on physiological variables related to energy metabolism in the male Fischer 344 rat. Mech. Ageing Dev. 48: 117-133.

Duffy, P.H., Feuers, R., Nakamura, K.D., Leakey, J., and Hart, R.W. 1990. Effect of chronic caloric restriction on the synchronization of various physiological measures in old female Fischer 344 rats. Chronobiol. Int. 7: 113-124.

Dukes, I.D., McIntyre, M.S., Mertz, R.J., Philipson, L.H., Roe, M.W., Spencer, B., and Worley III, J.F. 1994. Dependence on NADH produced during glycolysis for $\beta$-cell glucose signaling. J. Biol. Chem. 269: 10979-10982.

Engelman, R.W., Day, N.K., Chen, R.F., Tomita, Y., Bauer-Sardina, I., Dao, M.L., and Good, R.A. 1990. Calorie consumption level influences development of $\mathrm{C} 3 \mathrm{H} / \mathrm{Ou}$ breast adenocarcinoma with indifference to calorie source. Proc. Soc. Exp. Biol. Med. 193: 23-30.

Eto, K., Tsubamoto, Y., Terauchi, Y., Sugiyama, T., Kishimoto, T., Takahashi, N., Yamauchi, N., Kubota, N., Murayama, S., Aizawa, T., et al. 1999. Role of NADH shuttle system in glucose-induced activation of mitochondrial metabolism and insulin secretion. Science 283: 981-985.

Fernandes, G. and Good, R.A. 1984. Inhibition by restrictedcalorie diet of lymphoproliferative disease and renal damage in MRL/lpr mice. Proc. Natl. Acad. Sci. 81: 6144-6148.

Fernandes, G., Yunis, E.J., and Good, R.A. 1976. Suppression of adenocarcinoma by the immunological consequences of calorie restriction. Nature 263: 504-507.

Finch, C.E. and Ruvkun, G. 2001. The genetics of aging. Annu. Rev. Genomics Hum. Genet. 2: 435-462.

Finch, C.E., Felicio, L.S., Mobbs, C.V., and Nelson, J.F. 1984. Ovarian and steroidal influences on neuroendocrine aging processes in female rodents. Endocr. Rev. 5: 467-497.

Fraga, C.G., Shigenaga, M.K., Park, J.W., Degan, P., and Ames, B.N. 1990. Oxidative damage to DNA during aging: 8-Hydroxy-2'-deoxyguanosine in rat organ DNA and urine. Proc. Natl. Acad. Sci. 87: 4533-4537.

Gracy, R.W., Chapman, M.L., Cini, J.K., Jahani, M., Tollefsbol, T.O., and Yuksel, K.U. 1985. Molecular basis of the accumulation of abnormal proteins in Progeria and aging fibroblasts. Basic Life Sci. 35: 427-442.

Greene, A.E., Todorova, M.T., McGowan, R., and Seyfried, T.N. 2001. Caloric restriction inhibits seizure susceptibility in epileptic EL mice by reducing blood glucose. Epilepsia
42: $1371-1378$.

Guarente, L. and Kenyon, C. 2000. Genetic pathways that regulate ageing in model organisms. Nature 408: 255-262.

Harman, D. 1988. Free radicals in aging. Mol. Cell. Biochem. 84: $155-161$.

Harrison, D. 1989. Natural selection for extended longevity from food restriction. Growth Dev. Aging 53: 3-6.

Hauck, S.J. and Bartke, A. 2000. Effects of growth hormone on hypothalamic catalase and $\mathrm{Cu} / \mathrm{Zn}$ superoxide dismutase. Free Radic. Biol. Med. 28: 970-978.

Head, E., Liu, J., Hagen, T.M., Muggenburg, B.A., Milgram, N.W., Ames, B.N., and Cotman, C.W. 2002. Oxidative damage increases with age in a canine model of human brain aging. J. Neurochem. 82: 375-381.

Holliday, R. 1989. Food, reproduction and longevity: Is the extended lifespan of calorie-restricted animals an evolutionary adaptation? Bioessays 10: 125-127.

Holt, P.R., Moss, S.F., Heydari, A.R., and Richardson, A. 1998. Diet restriction increases apoptosis in the gut of aging rats. $J$. Gerontol. A Biol. Sci. Med. Sci. 53: B168-B172.

Imai, S., Armstrong, C.M., Kaeberlein, M., and Guarente, L. 2000. Transcriptional silencing and longevity protein Sir2 is an NAD-dependent histone deacetylase. Nature 403: 795800.

Ingram, D.K., Weindruch, R., Spangler, E.L., Freeman, J.R., and Walford, R.L. 1987. Dietary restriction benefits learning and motor performance of aged mice. J. Gerontol. 42: 78-81.

James, S.J., Muskhelishvili, L., Gaylor, D.W., Turturro, A., and Hart, R. 1998. Upregulation of apoptosis with dietary restriction: Implications for carcinogenesis and aging. Environ. Health Perspect. 106 Suppl 1: 307-312.

Jiang, J.C., Jaruga, E., Repnevskaya, M.V., and Jazwinski, S.M. 2000. An intervention resembling caloric restriction prolongs life span and retards aging in yeast. FASEB J. 14: 2135 2137.

Jiang, J., Wawryn, J., Shantha Kumara, H., and Jazwinski, S. 2002. Distinct roles of processes modulated by histone deacetylases Rpd3p, Hdalp, and Sir2p in life extension by caloric restriction in yeast. Exp. Gerontol. 37: 1023.

Johnson, P.R., Stern, J.S., Horwitz, B.A., Harris Jr., R.E., and Greene, S.F. 1997. Longevity in obese and lean male and female rats of the Zucker strain: Prevention of hyperphagia. Am. J. Clin. Nutr. 66: 890-903.

Kaeberlein, M., McVey, M., and Guarente, L. 1999. The SIR2/ 3/4 complex and SIR2 alone promote longevity in Saccharomyces cerevisiae by two different mechanisms. Genes \& Dev. 13: 2570-2580.

Keenan, K.P., Soper, K.A., Hertzog, P.R., Gumprecht, L.A., Smith, P.F., Mattson, B.A., Ballam, G.C., and Clark, R.L. 1995. Diet, overfeeding, and moderate dietary restriction in control Sprague-Dawley rats: II. Effects on age-related proliferative and degenerative lesions. Toxicol. Pathol. 23: 287302.

Kenyon, C., Chang, J., Gensch, E., Rudner, A., and Tabtiang, R. 1993. A C. elegans mutant that lives twice as long as wild type. Nature 366: 461-464.

Kimura, K.D., Tissenbaum, H.A., Liu, Y., and Ruvkun, G. 1997. daf-2, an insulin receptor-like gene that regulates longevity and diapause in Caenorhabditis elegans. Science 277: 942946.

Klebanov, S, Diais, S., Stavinoha, W.B., Suh, Y., and Nelson, J.F. 1995. Hyperadrenocorticism, attenuated inflammation, and the life-prolonging action of food restriction in mice. J. Gerontol. A Biol. Med. Sci. 50: B79-B82.

Kubo, C., Day, N.K., and Good, R.A. 1984. Influence of early or late dietary restriction on life span and immunological pa- 
rameters in MRL/Mp-lpr/lpr mice. Proc. Natl. Acad. Sci. 81: $5831-5835$.

Landfield, P.W. 1978. An endocrine hypothesis of brain aging and studies on brain-endocrine correlations and monosynaptic neurophysiology during aging. Adv. Exp. Med. Biol. 113: $179-199$.

Landry, J., Slama, J.T., and Sternglanz, R. 2000. Role of $\mathrm{NAD}^{+}$in the deacetylase activity of the SIR2-like proteins. Biochem. Biophys. Res. Commun. 278: 685-690.

Lane, M.A., Baer, D.J., Rumpler, W.V., Weindruch, R., Ingram, D.K., Tilmont, E.M., Cutler, R.G., and Roth, G.S. 1996. Calorie restriction lowers body temperature in rhesus monkeys, consistent with a postulated anti-aging mechanism in rodents. Proc. Natl. Acad. Sci. 93: 4159-4164.

Lane, M.A., Black, A., Handy, A., Tilmont, E.M., Ingram, D.K., and Roth, G.S. 2001. Caloric restriction in primates. Ann. NY Acad. Sci. 928: 287-295.

Laron, Z. 2002. Effects of growth hormone and insulin-like growth factor 1 deficiency on ageing and longevity. Novartis Found. Symp. 242: 125-142.

Lavie, L., Reznick, A.Z., and Gershon, D. 1982. Decreased protein and puromycinyl-peptide degradation in livers of senescent mice. Biochem. J. 202: 47-51.

Lee, A.T. and Cerami, A. 1992. Role of glycation in aging. Ann. NY Acad. Sci. 663: 63-70.

Lee, D.W. and Yu, B.P. 1990. Modulation of free radicals and superoxide dismutases by age and dietary restriction. Aging (Milano) 2: 357-362.

Lee, C.K., Klopp, R.G., Weindruch, R., and Prolla, T.A. 1999. Gene expression profile of aging and its retardation by caloric restriction. Science 285: 1390-1393.

Lee, C.K., Weindruch, R., and Prolla, T.A. 2000. Gene-expression profile of the ageing brain in mice. Nat. Genet. 25: 294 297.

Lin, S.J., Defossez, P.A., and Guarente, L. 2000. Requirement of NAD and SIR2 for life-span extension by calorie restriction in Saccharomyces cerevisiae. Science 289: 2126-2128.

Lin, S.J., Kaeberlein, M., Andalis, A.A., Sturtz, L.A., Defossez, P.A., Culotta, V.C., Fink, G.R., and Guarente, L. 2002. Calorie restriction extends Saccharomyces cerevisiae lifespan by increasing respiration. Nature 418: 344-348.

Liu, J., Head, E., Gharib, A.M., Yuan, W., Ingersoll, R.T., Hagen, T.M., Cotman, C.W., and Ames, B.N. 2002. Memory loss in old rats is associated with brain mitochondrial decay and RNA/DNA oxidation: Partial reversal by feeding acetyl-Lcarnitine and/or R- $\alpha$-lipoic acid. Proc. Natl. Acad. Sci. 99: 2356-2361.

Longo, V.D., Liou, L.L., Valentine, J.S., and Gralla, E.B. 1999. Mitochondrial superoxide decreases yeast survival in stationary phase. Arch. Biochem. Biophys. 365: 131-142.

Luo, J., Nikolaev, A.Y., Imai, S., Chen, D., Su, F., Shiloh, A., Guarente, L., and Gu, W. 2001. Negative control of p53 by Sir2 $\alpha$ promotes cell survival under stress. Cell 107: 137-148.

Masoro, E.J., Compton, C., Yu, B.P., and Bertrand, H. 1983. Temporal and compositional dietary restrictions modulate age-related changes in serum lipids. J. Nutr. 113: 880-892.

Masoro, E.J., Katz, M.S., and McMahan, C.A. 1989. Evidence for the glycation hypothesis of aging from the food-restricted rodent model. J. Gerontol. 44: B20-B22.

Masoro, E.J., McCarter, R.J., Katz, M.S., and McMahan, C.A. 1992. Dietary restriction alters characteristics of glucose fuel use. J. Gerontol. 47: B202-B208.

Mattson, M.P. 2000. Neuroprotective signaling and the aging brain: Take away my food and let me run. Brain Res. 886: $47-53$.

McCarter, R.J. and McGee, J.R. 1989. Transient reduction of metabolic rate by food restriction. Am. J. Physiol. 257: E175E179.

McCarter, R., Masoro, E.J., and Yu, B.P. 1985. Does food restriction retard aging by reducing the metabolic rate? Am. I. Physiol. 248: E488-E490.

McCay, C.M., Cromwell, M.F., and Maynard, L.A. 1935. The effect of retarded growth upon the length of life span and upon the ultimate body size. J. Nutr. 10: 63-79.

Migliaccio, E., Giorgio, M., Mele, S., Pelicci, G., Reboldi, P., Pandolfi, P.P., Lanfrancone, L., and Pelicci, P.G. 1999. The p66shc adaptor protein controls oxidative stress response and life span in mammals. Nature 402: 309-313.

Miller, R.A., Austad, S., Burke, D., Chrisp, C., Dysko, R., Galecki, A., Jackson, A., and Monnier, V. 1999. Exotic mice as models for aging research: Polemic and prospectus. Neurobiol. Aging 20: 217-231.

Mobbs, C.V., Bray, G.A., Atkinson, R.L., Bartke, A., Finch, C.E., Maratos-Flier, E., Crawley, J.N., and Nelson, J.F. 2001. Neuroendocrine and pharmacological manipulations to assess how caloric restriction increases life span. J. Gerontol. A Biol. Sci. Med. Sci. 56 Spec No 1: 34-44.

Moroi-Fetters, S.E., Mervis, R.F., London, E.D., and Ingram, D.K. 1989. Dietary restriction suppresses age-related changes in dendritic spines. Neurobiol. Aging 10: 317-322.

Nelson, J.F., Karelus, K., Bergman, M.D., and Felicio, L.S. 1995. Neuroendocrine involvement in aging: Evidence from studies of reproductive aging and caloric restriction. Neurobiol. Aging 16: 837-856.

Nemoto, S. and Finkel, T. 2002. Redox regulation of forkhead proteins through a p66shc-dependent signaling pathway. Science 295: 2450-2452.

Parkes, T.L., Elia, A.J., Dickinson, D., Hilliker, A.J., Phillips, J.P., and Boulianne, G.L. 1998. Extension of Drosophila lifespan by overexpression of human SOD1 in motorneurons. Nat. Genet. 19: 171-174.

Pedersen, W.A. and Mattson, M.P. 1999. No benefit of dietary restriction on disease onset or progression in amyotrophic lateral sclerosis $\mathrm{Cu} / \mathrm{Zn}$-superoxide dismutase mutant mice. Brain Res. 833: 117-120.

Reaven, E., Wright, D., Mondon, C.E., Solomon, R., Ho, H., and Reaven, G.M. 1983. Effect of age and diet on insulin secretion and insulin action in the rat. Diabetes 32: 175-180.

Richardson, A. 1985. The effect of age and nutrition on protein synthesis by cells and tissues from mammals. In Handbook of nutrition in the aged (ed. W.R. Watson), pp. 31-48. CRC Press, Boca Raton, FL.

Sapolsky, R.M., Krey, L.C., and McEwen, B.S. 1986. The neuroendocrinology of stress and aging: The glucocorticoid cascade hypothesis. Endocr. Rev. 7: 284-301.

Sarkar, N.H., Fernandes, G., Telang, N.T., Kourides, I.A., and Good, R.A. 1982. Low-calorie diet prevents the development of mammary tumors in $\mathrm{C} 3 \mathrm{H}$ mice and reduces circulating prolactin level, murine mammary tumor virus expression, and proliferation of mammary alveolar cells. Proc. Natl. Acad. Sci. 79: 7758-7762.

Scrofano, M.M., Shang, F., Nowell Jr., T.R., Gong, X., Smith, D.E., Kelliher, M., Dunning, J., Mura, C.V., and Taylor, A. 1998. Aging, calorie restriction and ubiquitin-dependent proteolysis in the livers of Emory mice. Mech. Ageing Dev. 101: 277-296.

Sell, D.R., Lane, M.A., Johnson, W.A., Masoro, E.J., Mock, O.B., Reiser, K.M., Fogarty, J.F., Cutler, R.G., Ingram, D.K., Roth, G.S., et al. 1996. Longevity and the genetic determination of collagen glycoxidation kinetics in mammalian senescence. Proc. Natl. Acad. Sci. 93: 485-490.

Semsei, I., Rao, G., and Richardson, A. 1989. Changes in the 
expression of superoxide dismutase and catalase as a function of age and dietary restriction. Biochem. Biophys. Res. Commun. 164: 620-625.

Shields, B.A., Engelman, R.W., Fukaura, Y., Good, R.A., and Day, N.K. 1991. Calorie restriction suppresses subgenomic mink cytopathic focus-forming murine leukemia virus transcription and frequency of genomic expression while impairing lymphoma formation. Proc. Natl. Acad. Sci. 88: 1113811142.

Sinclair, D.A. and Guarente, L. 1997. Extrachromosomal rDNA circles-A cause of aging in yeast. Cell 91: 1033-1042.

Smith, M.A., Taneda, S., Richey, P.L., Miyata, S., Yan, S.D., Stern, D., Sayre, L.M., Monnier, V.M., and Perry, G. 1994. Advanced Maillard reaction end products are associated with Alzheimer disease pathology. Proc. Natl. Acad. Sci. 91: 5710-5714.

Smith, J.S., Brachmann, C.B., Celic, I., Kenna, M.A., Muhammad, S., Starai, V.J., Avalos, J.L., Escalante-Semerena, J.C., Grubmeyer, C., Wolberger, C., et al. 2000. A phylogenetically conserved $\mathrm{NAD}^{+}$-dependent protein deacetylase activity in the Sir2 protein family. Proc. Natl. Acad. Sci. 97: 6658-6663.

Sohal, R.S. and Weindruch, R. 1996. Oxidative stress, caloric restriction, and aging. Science 273: 59-63.

Sornson, M.W., Wu, W., Dasen, J.S., Flynn, S.E., Norman, D.J., O'Connell, S.M., Gukovsky, I., Carriere, C., Ryan, A.K., Miller, A.P., et al. 1996. Pituitary lineage determination by the Prophet of Pit-1 homeodomain factor defective in Ames dwarfism. Nature 384: 327-333.

Stadtman, E.R. 1992. Protein oxidation and aging. Science 257: $1220-1224$.

Taylor, A., Zuliani, A.M., Hopkins, R.E., Dallal, G.E., Treglia, P., Kuck, J.F., and Kuck, K. 1989. Moderate caloric restriction delays cataract formation in the Emory mouse. FASEB $J$. 3: 1741-1746.

Tissenbaum, H.A. and Guarente, L. 2001. Increased dosage of a sir-2 gene extends lifespan in Caenorhabditis elegans. $\mathrm{Na}$ ture 410: 227-230.

Tran, H., Brunet, A., Grenier, J.M., Datta, S.R., Fornace Jr., A.J., DiStefano, P.S., Chiang, L.W., and Greenberg, M.E. 2002. DNA repair pathway stimulated by the forkhead transcription factor FOXO3a through the Gadd45 protein. Science 296: $530-534$.

Trinei, M., Giorgio, M., Cicalese, A., Barozzi, S., Ventura, A., Migliaccio, E., Milia, E., Padura, I.M., Raker, V.A., Maccarana, M., et al. 2002. A p53-p66Shc signalling pathway controls intracellular redox status, levels of oxidation-damaged DNA and oxidative stress-induced apoptosis. Oncogene 21: 3872-3878.

Tyner, S.D., Venkatachalam, S., Choi, J., Jones, S., Ghebranious, N., Igelmann, H., Lu, X., Soron, G., Cooper, B., Brayton, C., et al. 2002. p53 mutant mice that display early ageing-associated phenotypes. Nature 415: 45-53.

Vaziri, H., Dessain, S.K., Ng Eaton, E., Imai, S.I., Frye, R.A., Pandita, T.K., Guarente, L., and Weinberg, R.A. 2001. hSIR2(SIRT1) functions as an NAD-dependent p53 deacetylase. Cell 107: 149-159.

Vergnes, B., Sereno, D., Madjidian-Sereno, N., Lemesre, J.L., and Ouaissi, A. 2002. Cytoplasmic SIR2 homologue overexpression promotes survival of Leishmania parasites by preventing programmed cell death. Gene 296: 139-150.

Weindruch, R. and Sohal, R.S. 1997. Seminars in medicine of the Beth Israel Deaconess Medical Center. Caloric intake and aging. N. Engl. J. Med. 337: 986-994.

Weindruch, R. and Walford, R.L. 1988. The retardation of aging and disease by dietary restriction. CC Thomas, Springfield, IL.
Weindruch, R., Walford, R.L., Fligiel, S., and Guthrie, D. 1986. The retardation of aging in mice by dietary restriction: Longevity, cancer, immunity and lifetime energy intake. J. Nutr. 116: 641-654.

Weindruch, R., Keenan, K.P., Carney, J.M., Fernandes, G., Feuers, R.J., Floyd, R.A., Halter, J.B., Ramsey, J.J., Richardson, A., Roth, G.S., et al. 2001. Caloric restriction mimetics: Metabolic interventions. J. Gerontol. A Biol. Sci. Med. Sci. 56 Spec No 1: 20-33.

Yang, X.J., Kow, L.M., Funabashi, T., and Mobbs, C.V. 1999. Hypothalamic glucose sensor: Similarities to and differences from pancreatic $\beta$-cell mechanisms. Diabetes 48: 1763-1772.

Zhu, H., Guo, Q., and Mattson, M.P. 1999. Dietary restriction protects hippocampal neurons against the death-promoting action of presenilin-1 mutation. Brain Res. 842: 224-229. 


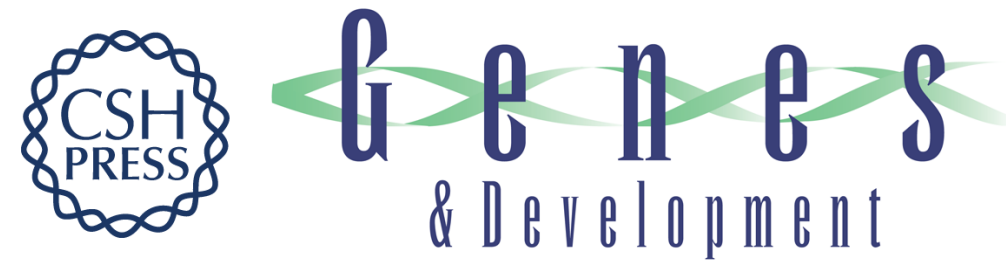

\section{How does calorie restriction work?}

Jana Koubova and Leonard Guarente

Genes Dev. 2003, 17:

Access the most recent version at doi:10.1101/gad.1052903

References This article cites 96 articles, 27 of which can be accessed free at: http://genesdev.cshlp.org/content/17/3/313.full.html\#ref-list-1

License

Email Alerting Receive free email alerts when new articles cite this article - sign up in the box at the top Service right corner of the article or click here.

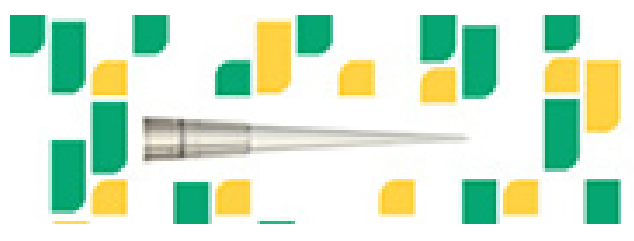

Focused on your science. 